Mеталлофиз. новейшие технол. / Metallofiz. Noveishie Tekhnol. (C) 2016 ИМФ (Институт металлофизики 2016 , т. 38, № 4, cc. 455-475 / DOI: 10.15407/mfint.38.04.0455 им. Г. В. Курдюмова НАН Украины) Оттиски доступны непосредственно от издателя

Фотокопирование разрешено только

Напечатано в Украине.

в соответствии с лицензией

PACS numbers: 61.05.cp, 61.72.Hh, 62.20.fq, 64.70.kd, 81.30.Hd, 81.30.Kf, 81.40.Lm

\title{
Carbon Distribution in Low-Temperature Isothermal Iron-Based Martensite and Its Tetragonality
}

\author{
V. G. Gavriljuk, S. A. Firstov*, V. A. Sirosh, A. I. Tyshchenko, \\ and G. S. Mogilny
}

\author{
G.V. Kurdyumov Institute for Metal Physics, N.A.S. of Ukraine, \\ 36 Academician Vernadsky Blvd., \\ UA-03680 Kyiv, Ukraine \\ "I. M. Frantsevich Institute for Problems of Materials Science, N.A.S. of Ukraine, \\ 3 Academician Krzhyzhanovs'kyy Blvd., \\ UA-03680 Kyiv, Ukraine
}

Carbon distribution in the as-quenched $\mathrm{Fe}-\mathrm{C}$ martensite obtained after cooling down to $4.5 \mathrm{~K}$ is studied using Mössbauer spectroscopy. The location of carbon atoms in the one of three available sublattices of octahedral interstitial sites is established, whereas the partial occupation by carbon atoms of tetrahedral sites or octahedral sites in other sublattices is not confirmed. The ageing of virgin isothermal martensite starts during heating at temperatures above $-50^{\circ} \mathrm{C}$ and leads to disappearance of single carbon atoms and their clustering in the $\alpha$ solid solution. In comparison with martensite obtained at room temperature, a decreased tetragonality of the low-temperature isothermal martensite and its partial recovery during ageing is observed. Based on the estimation of dislocation density and the absence of $\varepsilon$-carbide precipitation during subsequent tempering, a conclusion is made that plastic deformation occurs in the course of isothermal martensitic transformation because of the softness of the virgin martensite. Finally, a new interpretation of the abnormally low tetragonality is proposed, of which the essence is the capture and transport of immobile carbon atoms by gliding dislocations. As a result, a part of carbon is removed from the $\alpha$ solid solution and forms carbon atmospheres around the dislocations. The comparison of this hypothesis with available other ones is presented. Two possible reasons for partial recovery of

Corresponding author: Valentin Gennadievich Gavriljuk

E-mail: gavr@imp.kiev.ua

Please cite this article as: V. G. Gavriljuk, S. A. Firstov, V. A. Sirosh, A. I. Tyshchenko, and G. S. Mogilny, Carbon Distribution in Low-Temperature Isothermal Iron-Based Martensite and Its Tetragonality, Metallofiz. Noveishie Tekhnol., 38, No. 4: 455-475 (2016) (in English), DOI: 10.15407/mfint.38.04.0455. 
tetragonality during ageing of virgin martensite are discussed: (i) the unfreezing of Snoek atmospheres created by gliding dislocations crossing the immobile carbon atoms at low temperatures and (ii) coherent stresses at the boundaries of the intermittent carbon-rich and carbon-depleted domains in the modulated structure of the aged martensite.

Key words: isothermal martensitic transformation, plastic deformation, short-range atomic order, dislocations, tetragonality.

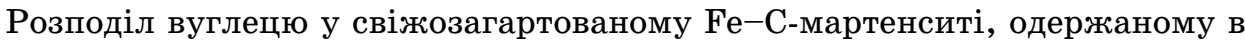
процесі охолодження до 4,5 К, досліджено методом Мессбауерівської спектроскопії. Встановлено розташування атомів Карбону в одній із трьох підгратниць октаедричних міжвузлів і не підтверджено часткову зайнятість ними інших підгратниць або тетраедричних міжвузлів. Розпад свіжозагартованого ізотермічного мартенситу починається при нагріванні вище $-50^{\circ} \mathrm{C}$ і приводить до зникнення поодиноких атомів вуглецю в $\alpha$ твердому розчині та утворення їх кластерів. У порівнянні з мартенситом, одержаним гартуванням за кімнатної температури, свіжозагартований низькотемпературний ізотермічний мартенсит характеризується зменшеною тетрагональністю, яка частково відновлюється при наступному нагріванні вище $-50^{\circ} \mathrm{C}$. Грунтуючись на оцінках густини дислокацій в одержаному низькотемпературному мартенситі та відсутності виділень $\varepsilon$ карбіду при наступному відпусканні, зроблено висновок, що, внаслідок низької міцности утвореного незастареного мартенситу, ізотермічне мартенситне перетворення супроводжується пластичною деформацією. В результаті запропоновано нову інтерпретацію аномально низької тетрагональности низькотемпературного мартенситу, суть якої полягає у захопленні та транспортуванні дислокаціями ковзання нерухомих атомів Карбону з видаленням їх із твердого розчину і утворенням Карбонових атмосфер в полі напружень дислокацій. Наведено її співставлення з наявними гіпотезами. Проаналізовано дві можливі причини часткового відновлення тетрагональности при старінні низькотемпературного мартенситу: (i) розморожування атмосфер Снука, утворених дислокаціями ковзання за низьких температур, i (ii) когерентні напруження на межах переміжних областей, збагачених та збіднених Карбоном у модульованій структурі застареного мартенситу.

Ключові слова: ізотермічне мартенситне перетворення, пластична деформація, близький атомовий порядок, дислокації, тетрагональність.

Распределение углерода в свежезакалённом $\mathrm{Fe}-\mathrm{C}$-мартенсите, полученном в процессе охлаждения до $4,5 \mathrm{~K}$, исследовано методом мёссбауэровской спектроскопии. Установлено размещение атомов углерода в одной из трёх подрешёток октаэдрических междоузлий и не подтверждена частичная занятость ими других подрешёток или тетраэдрических междоузлий. Распад свежезакалённого изотермического мартенсита начинается при нагреве выше $-50^{\circ} \mathrm{C}$ и приводит к исчезновению одиночных атомов углерода в $\alpha$-твёрдом растворе и образованию их кластеров. В сравнении с мартенситом, полученным закалкой при комнатной температуре, свежезакалённый низкотемпературный изотермический мартенсит характеризуется пониженной тетрагональностью, которая частично восстанавлива- 
ется при последующем нагреве выше $-50^{\circ} \mathrm{C}$. Основываясь на оценках плотности дислокаций в полученном мартенсите и отсутствии выделения $\varepsilon$-карбида при последующем отпуске, сделан вывод, что, вследствие низкой прочности образованного несостаренного мартенсита, изотермическое мартенситное превращение сопровождается пластической деформацией. В результате предложена новая интерпретация аномально низкой тетрагональности низкотемпературного мартенсита, суть которой заключается в захвате и транспорте дислокациями скольжения неподвижных атомов углерода с удалением их из твёрдого раствора и образованием углеродных атмосфер в поле напряжений дислокаций. Приведено её сопоставление с существующими гипотезами. Обсуждены две возможные причины частичного восстановления тетрагональности при старении низкотемпературного мартенсита: (i) размораживание атмосфер Снука, созданных движущимися дислокациями при низких температурах, и (ii) когерентные напряжения на границах чередующихся областей, обогащённых и обеднённых углеродом в модулированной структуре состаренного мартенсита.

Ключевые слова: изотермическое мартенситное превращение, пластическая деформация, ближний атомный порядок, дислокации, тетрагональность.

(Received February 10, 2016)

\section{INTRODUCTION}

First time, the isothermal martensitic transformation in the ironbased solid solutions was studied in detail by Kurdyumov and Maximova [1], although some indications were reported earlier (see, e.g., [25]). Its main feature is the transformation in the course of time at low temperatures. Since the first study by Kurdyumov and Maximova, it was the object of intensive research on the ferrous and nonferrous alloys, of which results were, e.g., summarized by Lobodyuk and Estrin $[6,7]$. The following features of the isothermal martensite in $\mathrm{Fe}-\mathrm{C}$ solid solutions are distinctive in comparison with that obtained in the nonferrous alloys and with the athermal $\mathrm{Fe}-\mathrm{C}$ martensite.

First, it is characterized by a low yield and ultimate strength and rather high plasticity [8-10]. Moreover, being integral part of the athermal iron-carbon martensitic transformation at ambient temperatures, the cracks are absent in the low-temperature isothermal martensite. Cracking starts only during its heating above $-50^{\circ} \mathrm{C}[9]$.

Second, the carbon atoms are essentially immobile during the isothermal martensitic transformation (e.g., [11]), which results in a virgin non-aged iron-carbon martensite. Its ageing starts during heating above $-50^{\circ} \mathrm{C}$ and results in the martensite decomposition into the areas rich and depleted in carbon alternately.

Third, the isothermal iron-carbon martensite is characterized by 
decreased tetragonality [12] in comparison with that formed at ambient temperatures. The tetragonality is partially recovered during heating to room temperature, although never reaches its expected value described by the relation $c / a=1+0.046 c_{\mathrm{C}}$, where $c_{\mathrm{C}}$ is the carbon concentration in mass \%. The abnormally low tetragonality was found after low-temperature martensitic transformation in $\mathrm{Fe}-\mathrm{Mn}-\mathrm{C}$ [12], $\mathrm{Fe}-$ $\mathrm{Ni}-\mathrm{C}$ at a moderate $\mathrm{Ni}$ content of $8 \%$ [13], $\mathrm{Fe}-\mathrm{Re}-\mathrm{C}$ [14] and plain high carbon [15] martensites.

Two main hypotheses have been proposed to interpret the abnormally low tetragonality of the virgin iron-carbon martensite: (i) a partial location of carbon atoms in the tetrahedral interstitial sites resulted from the $\gamma \rightarrow \alpha^{\prime}$ martensitic transformation through the intermediate $\varepsilon$-phase [16]; (ii) a redistribution of carbon atoms among three sublattices of octahedral sites in the bcc crystal lattice due to a twinning on the (011) planes in the course of the low-temperature martensitic transformation [17]. According to the calculations [18], the occurrence of thin twin layers in the $\alpha$-iron lattice on the (011)[0 11] system can shift the maximum of intensity in the X-ray reflections, which seems to be consistent with the second hypothesis.

Later on, the abnormally high tetragonality was found in $\mathrm{Fe}-\mathrm{Al}-\mathrm{C}$ $[19,20]$ and, at rather high $\mathrm{Ni}$ contents, in $\mathrm{Fe}-\mathrm{Ni}-\mathrm{C}[21,22]$ martensites. Based on these findings, the hypothesis [17] of carbon distribution among different sublattices of octahedral interstitial sites has been updated [23], so that the occupation by carbon atoms of the only $c$ sublattice was supposed in case of high tetragonality, whereas the 'normal' tetragonality was attributed to a partial occupation of the $a$ and (or) $b$-sublattices, and the abnormally low tetragonality suggested an increase in this fraction of carbon atoms.

The attempt of a critical experiment was undertaken using the neutron diffraction [24], of which results supported the interpretation given in [17, 23] and rejected the hypothesis in [16]. However, the both hypotheses were at variance with results of studies carried out using Mössbauer spectroscopy (see, e.g., [25-27]).

This paper aims at the analysis of a mechanism for the abnormally low tetragonality of the low-temperature isothermal martensite taking into account its aforementioned properties, namely low strength of virgin martensite and immobility of carbon atoms at temperatures of the isothermal martensitic transformation. The occurrence of plastic deformation in the course of the isothermal transformation was the main idea tested in this study.

\section{EXPERIMENTAL}

The tool steel X153CrMoV12 containing (\% mass) $1.55 \mathrm{C}, 11.90 \mathrm{Cr}$, $0.70 \mathrm{~V}, 0.86 \mathrm{Mo}, 0.38 \mathrm{Si}, 0.33 \mathrm{Mn}, 0.05 \mathrm{~N}, 0.00 \mathrm{~S}, 0.02 \mathrm{P}, 0.00 \mathrm{Al}$ and a 
reference steel $100 \mathrm{Mn} 6$ were studied. The first one was chosen because, aiming the increase of their wear resistance, the tool steels are subjected to a deep cryogenic treatment where the isothermal martensitic transformation is expected. The second one has the fully austenitic structure and was first time used by Kurdyumov and Maximova [1] for studies of the isothermal martensitic transformation. Moreover, the abnormally low tetragonality of the low-temperature $\mathrm{Fe}-\mathrm{C}$ martensite was observed just on this steel by Lysak and Vovk [12].

For Mössbauer study of carbon distribution in the $\mathrm{Fe}-\mathrm{C}$ solid solution, the binary $\mathrm{Fe}-2.03 \%$ mass $\mathrm{C}$ alloy was obtained by the carburization of a pure iron foil of $20 \mu \mathrm{m}$ in thickness at $1150^{\circ} \mathrm{C}$ under flowing methane followed by quenching in water. The obtained fully austenitic specimen was cooled down to $4.5 \mathrm{~K}$ in the cryostat of Mössbauer spectrometer. Mössbauer measurements at $4.5 \mathrm{~K}$ revealed $(68 \pm 1) \%$ of the virgin martensite and $(32 \pm 1) \%$ of retained austenite. Thereafter, the sample was heated to $65 \mathrm{~K}$ and studied at this temperature after successive heating-cooling cycles within the temperature range between 65 and $293 \mathrm{~K}$ with holding for $10 \mathrm{~min}$ at each temperature.

The martensitic transformation in the above-mentioned tool steel was studied using Mössbauer spectroscopy, X-ray diffraction and mechanical spectroscopy. In addition, the TEM study of quenched samples after the low-temperature tempering was carried out aiming to clarify the effect of isothermal martensitic transformation on the precipitation of transient carbides.

Specimens of steel X153CrMoV12 with a size of $10 \times 10 \times 0.03 \mathrm{~mm}^{3}$ for Mössbauer spectroscopy, $10 \times 10 \times 0.1 \mathrm{~mm}^{3}$ for X-ray diffraction and TEM, $0.7 \times 0.7 \times 60 \mathrm{~mm}^{3}$ for internal friction were solution treated at $1150^{\circ} \mathrm{C}$ under protective argon atmosphere for $20 \mathrm{~min}$ followed by quenching at room temperature (RT) using the argon flow. After quenching at room temperature, the samples were subjected to deep cryogenic treatment for different times at temperatures of -196 and $-150^{\circ} \mathrm{C}$. A feature of this experiment was a rapid immersion in liquid nitrogen, measurements at this temperature, subsequent heating and holding at $-150^{\circ} \mathrm{C}$ and measurements at $-196^{\circ} \mathrm{C}$. Such a technique allowed one to keep the same cooling rate in the temperature range between RT and the temperature of the isothermal treatment. As shown in [28], the holding at $-196^{\circ} \mathrm{C}$ is not accompanied by any transformation because of too low thermal activation.

A WISSEL Mössbauer spectrometer and a source of $\gamma$-quanta ${ }^{57} \mathrm{Co}$ in a Cr matrix with an activity of $50 \mathrm{mCi}$ were used for the measurements. The equipment was characterized by a line-width of $0.22 \mathrm{~mm} / \mathrm{s}$ for the line of the $\gamma$-quanta source.

The X-ray diffraction measurements were carried out with $\mathrm{Fe} K_{\alpha^{-}}$ radiation using a Huber diffractometer with the operating voltage of $30 \mathrm{kV}$ and one-circle $\Theta-2 \Theta$-goniometer. A computer program con- 
trolled the angular movement of both the goniometer and the counter. A cryosystem LN-3 produced by Cryo Industries of America Inc. was used for measurements at low temperatures. In contrast to standard cryostats, this system allows a rapid cooling of the sample installed in the diffractometer, its holding and measurements at any temperature within the range of 20 to $-196^{\circ} \mathrm{C}$. With our samples, the lowest achieved temperature was $-182^{\circ} \mathrm{C}$.

An automated inverted pendulum with frequencies close to $1 \mathrm{~Hz}$ was used for obtaining the IF spectra within the temperature range of -190 to $600^{\circ} \mathrm{C}$. The heating/cooling rate was about $1.5 \mathrm{~K} / \mathrm{min}$.

A JEM-2000 FXII transmission electron microscope, operating at a voltage of $200 \mathrm{kV}$, was used for structural studies in the transmission mode. Diffraction patterns from the areas of about $0.5 \mu \mathrm{m}$ in size were obtained by the conventional selected area diffraction (SAD) technique.

\section{CARBON DISTRIBUTION IN THE VIRGIN MARTENSITE}

Mössbauer spectra of $\mathrm{Fe}-2.03 \% \mathrm{C}$ solid solution are presented in Fig. $1, a$ after cooling down to $4.5 \mathrm{~K}$, measuring at this temperature, heating up to $65 \mathrm{~K}\left(-208^{\circ} \mathrm{C}\right)$ and subsequent measuring at this temperature after holdings for $10 \mathrm{~min}$ at temperatures within the range in between $-208^{\circ} \mathrm{C}$ and RT. Figure 1, $b$ shows the outer lines of these spectra (nuclear transition $-1 / 2 \rightarrow-3 / 2$ ).

It is worth noting that either the fraction of the retained austenite, $(32 \pm 1) \%$, or that of the martensite, $(68 \pm 1) \%$, be measured at $4.5 \mathrm{~K}$, were not changed due to heating to $65 \mathrm{~K}\left(-208^{\circ} \mathrm{C}\right)$ and subsequent holdings in between this temperature and RT. This result is at variance with the data presented in [29], where, using the uniaxial dilatometry, the inverse martensite-to-austenite transformation at low temperatures was mentioned to occur in the alloy of similar composition $\mathrm{Fe}-$ $1.95 \% \mathrm{C}$, as well as in the alloy $\mathrm{Fe}-1.60 \% \mathrm{C}-2.24 \% \mathrm{Mn}$. Possibly, the relaxation of stresses during heating should be taken into account, if the dilatometry is used for studies of metastable martensitic phases.

The stability of the retained austenite in the course of heating to RT gives also the evidence that the isothermal martensitic transformation in the studied binary $\mathrm{Fe}-\mathrm{C}$ alloy proceeded only in the course of cooling.

\subsection{Interpretation of Mössbauer Spectrum}

The virgin and aged $\mathrm{Fe}-\mathrm{C}$ martensites were the object of a number of Mössbauer studies (see, e.g., [25-27, 30-38]). So far, it is hardly possible to carry out ab initio calculations of hyperfine structure parameters in such multicomponent spectra. As a test for validity of their in- 
terpretation, the change in the spectra caused by heating the virgin martensite to RT, can be used, taking into account the corresponding redistribution of carbon atoms and their additive effect on the hyperfine field $H_{\mathrm{i}}$ at the nuclei of nearest iron atoms, $\cong 0.3 \mathrm{~T}$ per one carbon atom [26, 39].

As a first approximation, the martensitic spectrum in Fig. 1, $b$ can be divided into 3 components $\mathrm{A}, \mathrm{B}$ and $\mathrm{C}$ characterized by different hyperfine fields $H_{\mathrm{i}}$ and belonging to iron atoms having no, one and two carbon atoms as nearest neighbours, respectively. At the same time, because of high sensitivity of the hyperfine field to local dilatations of the crystal lattice, different values of the isomeric shift and, particularly, the quadrupole interaction, can be revealed in each of these components.

The component $\mathrm{A}$ is approximated by sextets 1 and 2 with different values of the hyperfine field, $H_{\mathrm{i}}$, and a rather close isomer shift, $\delta$, and quadrupole interaction, $\varepsilon$. Sextet 1 with the highest $H_{\mathrm{i}}$ comes from pure iron atoms in the martensite. Its increased hyperfine field in comparison with that in the pure $\alpha$-iron is obviously caused by dilatation of the crystal lattice at the distances far from carbon atoms, in ac-

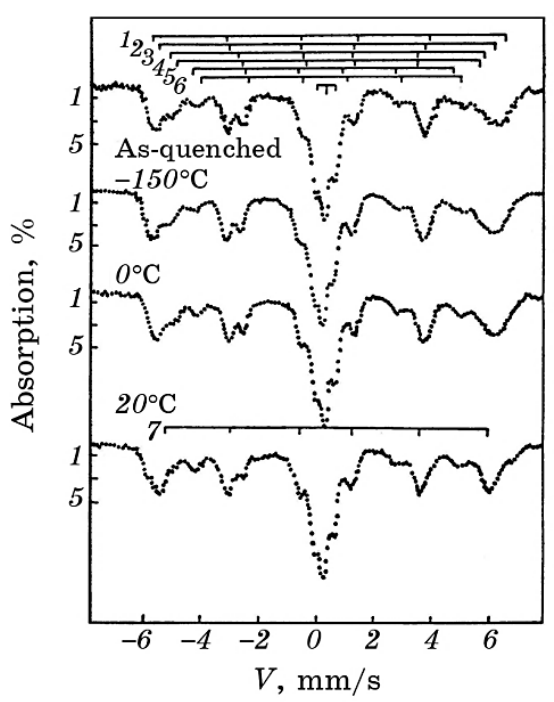

$a$

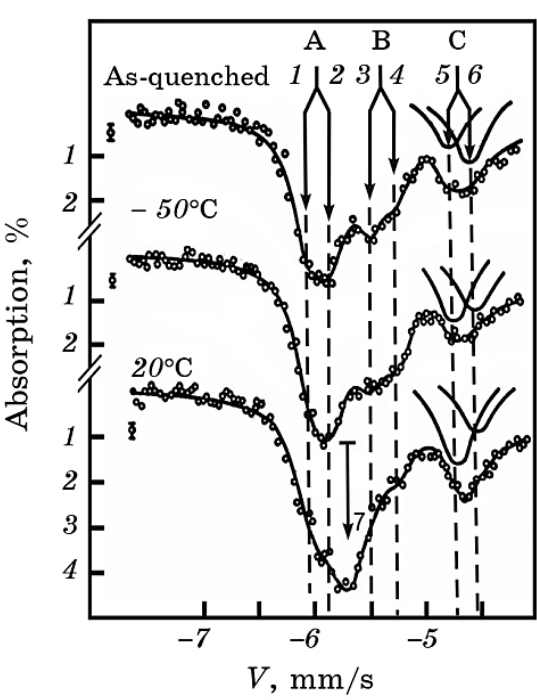

$b$

Fig. 1. Mössbauer spectra of the alloy F-2.03\% mass $\mathrm{C}$ after quenching in water, cooling to $4.5 \mathrm{~K}$, measurements at this temperature (as-quenched) and subsequent heating to different temperatures with holding for 10 min within the range of $-208^{\circ} \mathrm{C}$ to $\mathrm{RT}(a)$; outer lines (nuclear transition $-1 / 2 \rightarrow-3 / 2$ ) of selected spectra $(b)$. All measurements after heating were carried out at $65 \mathrm{~K}$ $\left(-208^{\circ} \mathrm{C}\right)$. 
cordance with the Bethe-Slater dependence of atomic magnetic moments on the interatomic distance. Sextet 2 can be attributed to atoms $\mathrm{Fe}_{1}^{\prime \prime \prime}$ in Fig. 2, configuration $a$, which are the third neighbours of the carbon atoms and only slightly subjected to the effect of carbon atoms.

After ageing at RT, the intensity of both sextets 1 and 2 decreases, see Fig. 1, $b$, and a new sextet 7 with the $H_{\mathrm{i}}$ typical for pure $\alpha$-iron becomes dominant in this component, because the decomposition of the supersaturated carbon $\alpha$ solid solution due to ageing is accompanied by formation of rather large not dilated domains of pure iron atoms.

Sextets 3 and 4 in the component $\mathrm{B}$ correspond to the iron atoms as second and first neighbours, respectively, of a single carbon atom in the octahedral site on the $c$ axis (atoms $\mathrm{Fe}_{1}^{\prime \prime}$ and $\mathrm{Fe}_{1}^{\prime}$ in the configuration $a$, see Fig. 2). The sign of the quadrupole interaction is different for these two kinds of atoms because of the different angle $\Theta$ between the electric field gradient $\mathbf{q}$ and direction of the axis of easy magnetization axis $\mathbf{H}$. The quadrupole interaction is described by the formula $\varepsilon=e^{2} q Q\left(3 \cos ^{2} \Theta-1\right) / 8$, where $e$ and $Q$ are the electron charge and the iron nuclear quadrupole moment, respectively. As $Q$ is positive in the b.c.c. iron [40] and $q$ is negative $[41,42]$, the quadrupole interaction $\varepsilon$ for $\mathrm{Fe}_{1}^{\prime}$ atoms should be negative and twice larger in comparison with $\mathrm{Fe}_{1}^{\prime \prime}$ atoms (see Fig. 2, $a$ and Table 1).

Sextets 5 and 6 are characterized the same hyperfine fields, smaller by $\cong 3 \mathrm{~T}$ than that for atoms $\mathrm{Fe}_{1}^{\prime}$, and different quadrupole interactions in their sign and by two times in the value. They belong to the iron at-

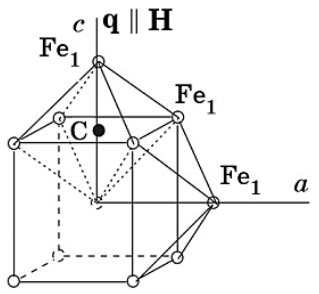

$a$

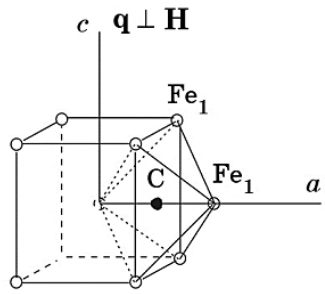

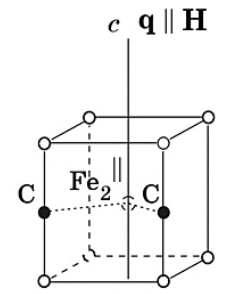

$c$

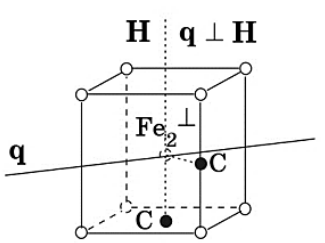

$d$

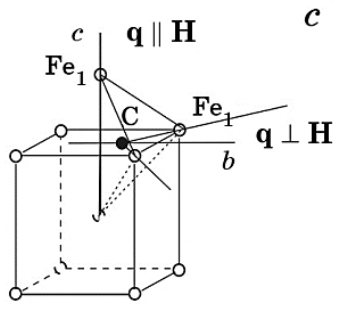

Fig. 2. Configurations of iron and carbon atoms as derived from the interpretation of Mössbauer spectra. $\mathbf{H}$ is the axis of easy magnetization; $\mathbf{q}$ is the electric field gradient. 
TABLE 1. Parameters of hyperfine structure in Mössbauer spectrum of Fe$2.03 \%$ mass $\mathrm{C}$ for the virgin martensite. Sextet 7 appears after ageing at $20^{\circ} \mathrm{C}$. Measurements at $65 \mathrm{~K}\left(-208^{\circ} \mathrm{C}\right)$.

\begin{tabular}{c|c|c|c}
\hline Sextet & Hyperfine field $H_{\mathrm{i}}, \mathrm{T}$ & $\begin{array}{c}\text { isomer shift (in relation to } \\
\alpha \text {-iron) } \delta \pm 0.005, \mathrm{~mm} / \mathrm{s}\end{array}$ & $\begin{array}{c}\text { Quadrupole interac- } \\
\text { tion } 4 \varepsilon, \mathrm{mm} / \mathrm{s}\end{array}$ \\
\hline 1 & $37.4 \pm 0.2$ & 0.207 & $0.027 \pm 0.005$ \\
2 & $35.7 \pm 0.3$ & 0.157 & $0.012 \pm 0.005$ \\
3 & $33.5 \pm 0.4$ & 0.124 & $0.076 \pm 0.01$ \\
4 & $31.6 \pm 0.4$ & 0.229 & $-0.210 \pm 0.01$ \\
5 & $28.0 \pm 0.3$ & 0.197 & $-0.512 \pm 0.01$ \\
6 & $27.8 \pm 0.3$ & -0.005 & $0.273 \pm 0.01$ \\
7 & $34.6 \pm 0.15$ & 0.096 & $0.009 \pm 0.01$ \\
\hline
\end{tabular}

oms $\mathrm{Fe}_{2}$ with two carbon atoms as nearest neighbours in the configurations $c$ and $d$, where the angle $\Theta$ is equal to zero or $90^{\circ}$, respectively.

After cooling within the temperature range in between $-208^{\circ} \mathrm{C}$ and $-50^{\circ} \mathrm{C}$, the spectra remain unchanged. A redistribution in the intensity of the components starts after heating above $-50^{\circ} \mathrm{C}$ (see Fig. 1, $b$ ). The component B caused by single carbon atoms essentially disappears, whereas the cluster component $\mathrm{C}$ increases its intensity. Due to ageing at RT, the outer lines are shifted to the gravity centre of the spectrum and the component 7 appears in the spectrum.

\subsection{Carbon Distribution in the Virgin and Aged Martensites}

The obtained data of Mössbauer studies allow carrying out the following analysis of available hypotheses about carbon distribution in the virgin low-temperature martensite and its change in the course of the ageing.

If some part of carbon atoms could be located in the $a$ - or $b$ sublattices of the octahedral interstitial sites, as proposed in [17], an additional component is expected in the spectrum having the hyperfine field equal to that for spectrum 4 but different quadrupole interaction $\varepsilon$ in the sign and by two times in the value (see configurations $a$ and $b$ in Fig. 2). This component should disappear in the course of heating within the temperature range of $-50^{\circ} \mathrm{C}$ up to $\mathrm{RT}$ when tetragonality starts to increase. However, such a component is not found in the spectrum.

Ino et al. [26] have analysed a hypothetic case of local turn in the axis of easy magnetization to follow the shift of carbon atoms into the $a$ or $b$-sublattices in the martensite. These authors have shown that the gain in the exchange energy for the alignment of the iron atom spins along the $c$ axis, $\mathbf{1 . 4} \cdot 10^{-20} \mathrm{~J}$, is by two orders of magnitude higher than 
the anisotropic energy, $1.0 \cdot 10^{-22} \mathrm{~J}$, by which the spin direction of neighbouring iron atoms could be locally turned along the $a$ or $b$ axes, if the carbon is located in those sublattices. Therefore, such local microdomains of differently oriented spins cannot exist within the $\alpha$-iron martensitic crystals.

For the same reason, a possible partial localization of carbon atoms in the tetrahedral sites of virgin martensite should be accompanied by two additional components in Mössbauer spectra with the hyperfine field close to that of component 4 and different quadrupole interactions (see configuration $e$ in Fig. 2).

Therefore, the hypotheses attributing the abnormally low tetragonality of virgin martensite to the localization of carbon atoms in the tetrahedral sites [16] or their distribution on the $a-, b$-, or $c$-sublattices of octahedral sites [17] (see configurations $e$ and $b$ in Fig. 1) are not consistent with the hyperfine structure of Mössbauer spectra of virgin martensite and their evolution during the heating.

The decrease in intensity of sextets 3 and 4 caused by single carbon atoms and the growth of sextets 5 and 6 belonging to carbon clusters at temperatures above $-50^{\circ} \mathrm{C}$ is consistent with the available observations of the decomposition and even formation of the modulated structure in the aged high-carbon martensites (e.g., $[43,44])$.

\section{PLASTIC DEFORMATION IN THE COURSE OF ISOTHERMAL MARTENSITIC TRANSFORMATION}

As follows from the X-ray diffraction measurements, Fig. 3, $a$, and data of mechanical spectroscopy, Fig. $3, b$, the isothermal martensitic transformation in the studied steel X153CrMoV12 proceeds within the temperature range in between $-100^{\circ} \mathrm{C}$ and $-170^{\circ} \mathrm{C}$ during cooling or heating with the maximal intensity at $-150^{\circ} \mathrm{C}$.

As a rule, due to the volume effect of phase transformations in substitutional solid solutions, they are accompanied by plastic deformation. This deformation is often used in cyclic $\gamma \rightarrow \alpha \rightarrow \gamma$ heat treatments for the accumulation of crystal lattice defects and corresponding strengthening.

However, it is not the case in carbon steels. Because of high mobility of carbon atoms at temperatures below $M_{\mathrm{s}}$ down to $-50^{\circ} \mathrm{C}$, the ageing of the freshly formed martensite occurs just in the course of its formation, which increases strength and hardness and, thereby, prevents plastic deformation. Moreover, it is ageing that causes cracking during martensitic transformation [9].

As mentioned above, the low-temperature isothermal martensite in carbon steels possesses a decreased strength and it is free of microcracks $[8,9]$. This feature along with the immobility of carbon atoms at temperatures below $-50^{\circ} \mathrm{C}$ is a hint that, like martensitic trans- 

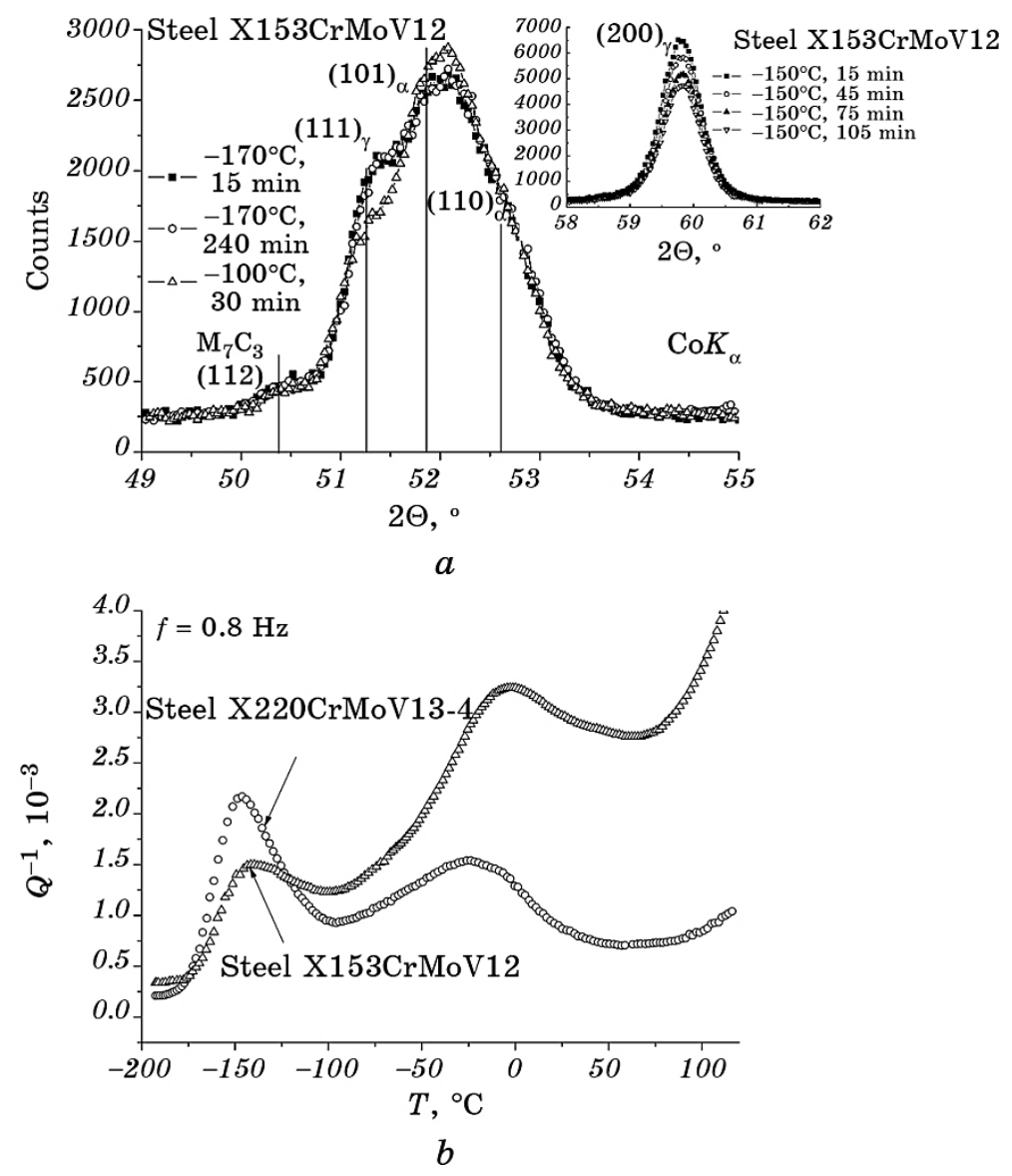

Fig. 3. Fragments of X-ray diffraction patterns of steel X153CrMoV12 after quenching from $1150^{\circ} \mathrm{C}$ at RT, holding at $-170^{\circ} \mathrm{C}$ for 15 and $240 \mathrm{~min}$ and subsequent holding at $-100^{\circ} \mathrm{C}$ for $30 \mathrm{~min}$. Evolution of the austenitic reflection $(200)_{\gamma}$ is shown in the upper left corner. Measurements at temperatures of holding (a); temperature dependence of internal friction in steels X153CrMoV12 and X220CrMoV13-4 in the course of heating after quenching in liquid nitrogen $(b)$.

formations in the substitutional solid solutions, plastic deformation can occur during martensitic transformations at sufficiently low temperatures.

Because of a complicated defect structure in the high-carbon steels and, having no possibility for TEM study in situ at low temperatures, two indirect experiments were carried out for testing this idea based on estimation of a change in dislocation density due to isothermal martensitic transformation and studies of the low-temperature $\varepsilon$-carbide precipitation during subsequent tempering. The latter aimed to test a 
possible competition between the binding enthalpy of carbon atoms in dislocation atmospheres and the enthalpy of $\varepsilon$-carbide formation.

In the first experiment, the Snoek-Köster (S-K) relaxation was measured, of which the source are the vibrations of dislocation segments. At other equal conditions, e.g. the strain amplitude and frequency, the relaxation strength is proportional to the density of dislocations. In Figure 4, the $\mathrm{S}-\mathrm{K}$ relaxation is presented for steel $\mathrm{X} 153 \mathrm{CrMoV} 12$ after quenching at RT without or with subsequent holding at $-196^{\circ} \mathrm{C}$ or $-150^{\circ} \mathrm{C}$ for 24 hours. The highest relaxation peak indicating to a largest dislocation density is obtained after holding at $-150^{\circ} \mathrm{C}$, where the isothermal transformation is the most intensive. As shown in [45], this growth of $\mathrm{S}-\mathrm{K}$ relaxation strength, $9 \%$, is much higher than the increment of the isothermal martensite fraction, $4 \%$, which could be another source of the increased dislocation density.

The idea of the second experiment is based on the old studies carried out by Wilson [46] who has shown that Vickers indentation test on the as-quenched $\mathrm{Fe}-0.8 \% \mathrm{C}$ martensite prevents the precipitation of $\varepsilon$ carbide during subsequent tempering.

The precipitation of the low-temperature $\varepsilon$-carbide during tempering of steel X153CrMoV12 is compared in case of quenching at RT, Fig. 5, and isothermal martensitic transformation at $-150^{\circ} \mathrm{C}$, Fig. 6 . The $\varepsilon$-carbide is clearly identified in Fig. 5 and is absent in Fig. 6, which is consistent with the observations made by Wilson. A reason for this phenomenon is the higher enthalpy of binding between dislocations and carbon atoms, $\cong 0.8 \mathrm{eV}$, and the heat solution of $\varepsilon$-carbide in the ferrite, $\cong 0.26 \mathrm{eV}$.

The distorted shape of reflections, see Fig. $6, c$, can be related to the

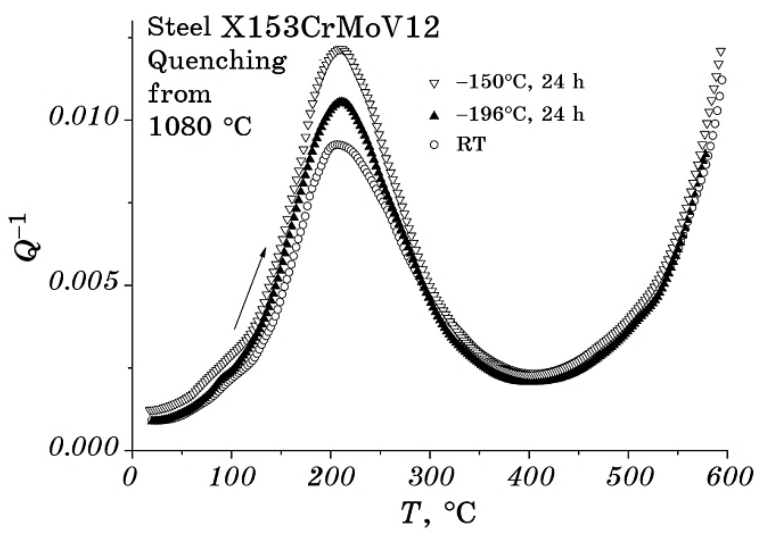

Fig. 4. Snoek-Köster relaxation in steel X153CrMoV12 after holding at -196 and $-150^{\circ} \mathrm{C}$ for 24 hours in comparison with conventional quenching at room temperature. 


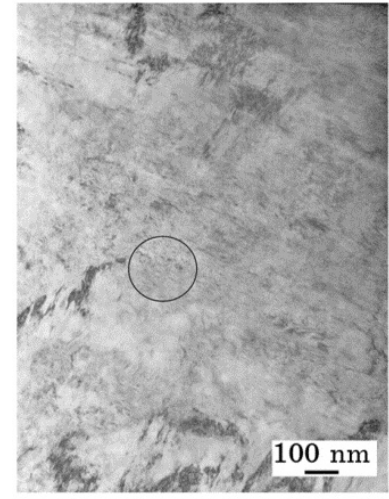

$a$

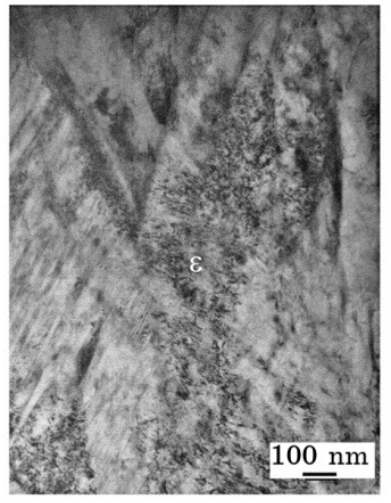

$b$

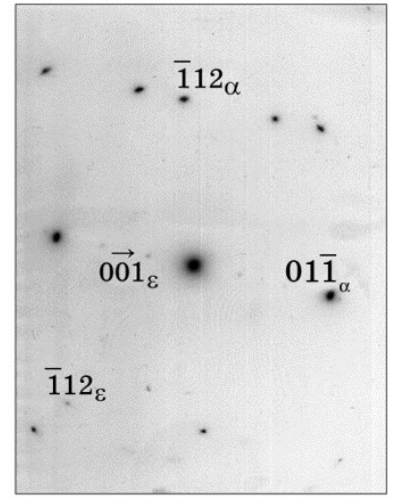

$c$

Fig. 5. Precipitates of $\varepsilon$-carbide after tempering at $100^{\circ} \mathrm{C}$ of steel $\mathrm{X} 153 \mathrm{CrMoV} 12$ quenched at RT. The $\varepsilon$-carbide was identified by diffraction from the area marked with a circle $(a)$; the same after tempering at $200^{\circ} \mathrm{C}(b)$; diffraction pattern after tempering at $200^{\circ} \mathrm{C}$, zone axes $[311]_{\alpha}$ and $[\overline{1} 12]_{\varepsilon}(c)$.

formation of satellites due to spinodal decomposition during the ageing of the low-temperature martensite, like it was observed earlier in $\mathrm{Fe}-\mathrm{Ni}-\mathrm{C}[43]$ and $\mathrm{Fe}-\mathrm{C}[44]$ alloys.

The total suppression of $\varepsilon$-carbide precipitation due to the isothermal martensitic transformation gives the evidence that, be initiated by the softness of virgin martensite, plastic deformation involves the total structure of steel including also the athermal martensite, in spite of its brittleness. This case can be compared with drawing or rolling of eutectoid steels containing the brittle plate cementite along with the soft ferrite.

\section{A MECHANISM FOR DECREASE OF TETRAGONALITY}

Plastic deformation in the course of the low-temperature isothermal martensitic transformation is expected to be accompanied by the capture and transport of immobile carbon atoms by gliding dislocations, which removes a part of carbon from the solid solution. If so, the tetragonality of the virgin martensite should be decreased. The main point in this hypothesis is a possibility for the transport of interstitial atoms by dislocations.

Theoretical and experimental studies of the transport of hydrogen atoms by dislocations were carried out mainly in the seventies [47-49]. In relation to carbon, it is worth to note the striking difference between the decrease of carbon mobility in the deformed steels and the enhanced carbon migration in the course of plastic deformation [50- 


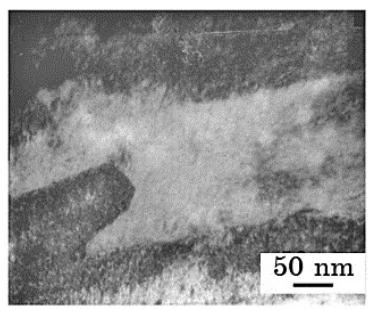

$a$

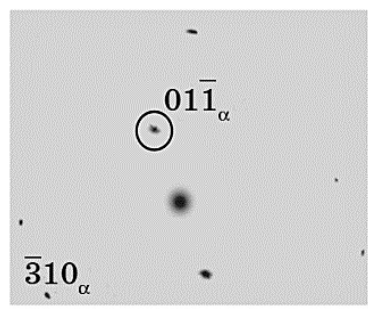

$b$

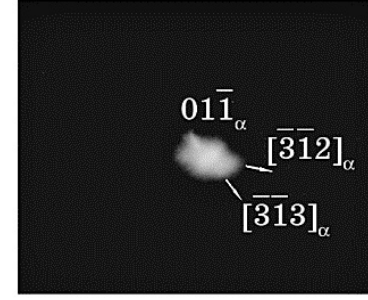

$c$

Fig. 6. Martensite after deep cryogenic treatment, DCT, at $-150^{\circ} \mathrm{C}$ and tempering at $100^{\circ} \mathrm{C}$ for $2 \mathrm{~h}(a)$; electron diffraction, zone axis [133] $]_{\alpha}(\mathrm{b})$; diffraction spot $[01 \overline{1}]_{\alpha}$ asymmetrical in directions $[\overline{3} \overline{1} 3]_{\alpha}$ and $[\overline{3} 12]_{\alpha}(c)$.

52]. This enhancement significantly exceeds the expected increase in the mechanical driving force for the diffusion flux. A non-activated mechanism for formation and transport of a 'dislocation-interstitial atom' complex was analysed within the scope of the Frenkel-Kontorova model in [53].

An indirect confirmation of carbon transfer by dislocations is presented by the phenomenon of cementite decomposition during plastic deformation of pearlitic steels by drawing or rolling. About $50 \%$ of cementite is decomposed due to severe plastic deformation of the eutectoid steel [54-56]. The degree of decomposition is controlled by the competition between $\mathrm{Fe}-\mathrm{C}$ bonding in the cementite lattice and the enthalpy of binding of carbon atoms to dislocations in the ferrite (see [57, 58]).

As shown in the quoted studies, the thin plate cementite is intensively decomposed during plastic deformation, whereas a smaller decomposition is found in case of the coarse plate cementite and no cementite decomposition occurs for the coarse grain cementite. The total cementite decomposition is obtained due to severe plastic deformation by the high-pressure torsion (e.g. [59]).

At the same time, there is no indication to any increase in the ferrite lattice parameter, and, therefore, practically no carbon from the decomposed cementite is dissolved in the $\alpha$ solid solution. This conclusion is also supported by Mössbauer studies [55-58], where the spectra are shown to consist of only two sextets from ferrite and cementite. No components caused by carbon in the $\alpha$ solid solution are present in Mössbauer spectra of cold worked pearlitic steels and only their intensity is changed due to partial decomposition of cementite.

Recently, using Local Electron Atom Probe study [60], it was found that carbon atoms of decomposed cementite in the severely deformed steel are located at the dislocations in the ferrite. Such a huge carbon concentration at the dislocations cannot be reached by a pulling of carbon atoms out of cementite lattice by dislocations with formation of 
Cottrell's atmospheres because, in contrast to Cottrell and Bilby analysis [61], these atmospheres are rather diluted [62].

In other words, to be decomposed, the cementite should be involved in deformation of pearlitic steels. As shown using transmission electron microscopy $[63,64]$, the cementite of plate morphology in pearlitic steels is plastically deformed during the drawing or rolling.

Therefore, a mechanism for the strain-induced cementite decomposition amounts to the cutting of cementite plates by the gliding dislocations followed by the capture of carbon atoms and their transfer into the ferrite with formation of carbon segregations around the dislocations.

Based on the aforementioned analysis, one can assume that a similar mechanism is operating in case of the low-temperature isothermal martensitic transformation, i.e. the plastic deformation results in the capture and transport of carbon atoms by gliding dislocations.

If so, it is particularly interesting to analyse the partial recovery of tetragonality during subsequent heating of the virgin martensite. The point is that, as mentioned above, because of a high enthalpy of binding between carbon atoms and dislocations, the atoms in dislocation atmospheres cannot contribute to the ageing of virgin martensite. Even the precipitation of the low-temperature $\varepsilon$-carbide is suppressed, if carbon atoms are located in the field stress of dislocations.

Steel $100 \mathrm{Mn} 6$ having $M_{\mathrm{s}}=-93^{\circ} \mathrm{C}$ and subjected to the isothermal martensitic transformation during holding at $-150^{\circ} \mathrm{C}$ was used for this study. The change in the martensite tetragonality during subsequent heating up to $+70^{\circ} \mathrm{C}$ is presented in Fig. 7. It is seen that tetragonality $c / a=1.026$ is much smaller of its value 1.047 expected for the $\mathrm{Fe}-\mathrm{C}$ martensite with $1.0 \%$ mass C. Its partial recovery up to $c / a=1.036$ occurs due to heating to $\mathrm{RT}$. At $+70^{\circ} \mathrm{C}$, the $c / a$ ratio starts to decrease.

According to hypotheses of $[16,17]$, the heating leads to jumping of carbon atoms from the tetrahedral to octahedral interstitial sites [16] or disappearance of (011) twins [17]. However, as shown in Section 3.2, no corresponding components appear in Mössbauer spectra of the virgin martensite and disappear in the course of its heating to RT. The effect of heating amounts only to the decrease in the fraction of single carbon atoms and increase in that of carbon clusters.

In view of the decisive role of plastic deformation in the decreased tetragonality of the low-temperature isothermal martensite, as proposed in this study, two possibilities for its partial recovery during heating can be analysed.

The first one concerns the interaction between gliding dislocations and immobile carbon atoms at low temperatures. One can imagine that some carbon atoms are not captured by crossing dislocations. In this case, the so-called Snoek atmospheres are formed, of which essence is a change in the ordering of carbon atoms, i.e., their jumping from the interstitial sites in the $c$-sublattice into those in the $a$ - or $b$-sublattices. 
In case of mobile carbon atoms, the Snoek atmospheres disappear immediately after dislocation passage because the Zener ordering returns carbon atoms into the $c$-sublattice. However, at temperatures below $-50^{\circ} \mathrm{C}$, this reverse jumping is impossible, which decreases tetragonality like it is proposed in hypothesis [17]. In the course of subsequent heating, at temperatures above $-50^{\circ} \mathrm{C}$, Zener ordering starts to be operating and results in jumping of carbon atoms back into the $c$ sublattice and recovery of tetragonality.

The only objection against this interpretation is that, like the case in

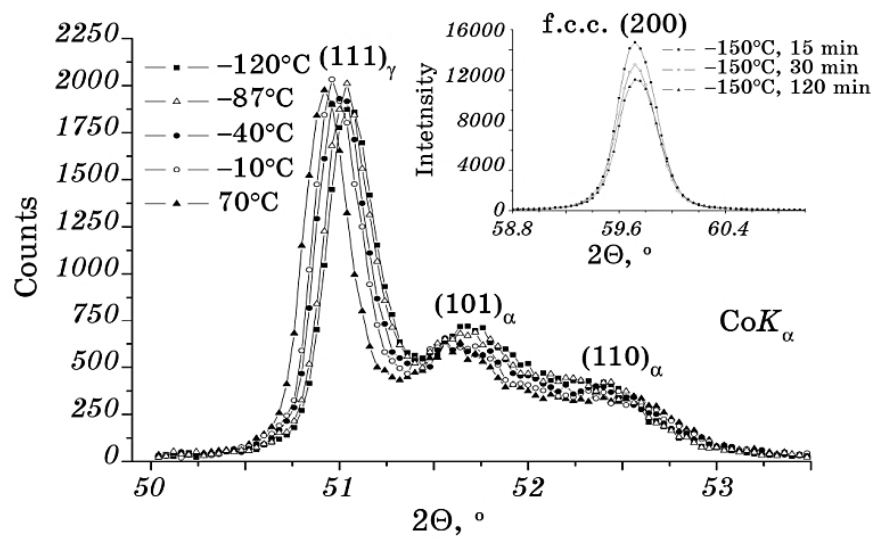

$a$

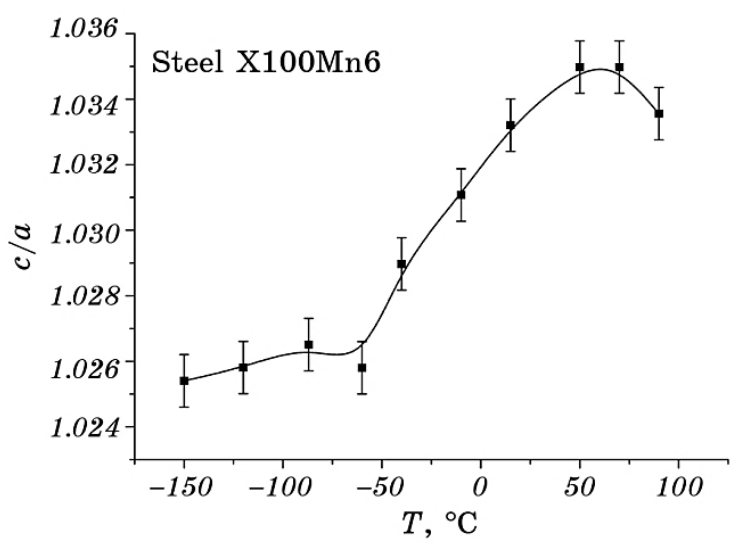

$b$

Fig. 7. Low-temperature X-ray diffraction of steel $100 \mathrm{Mn} 6$ after solution treatment at $1000^{\circ} \mathrm{C}$, isothermal martensitic transformation at $-150^{\circ} \mathrm{C}$ and subsequent heating: fragments of diffraction patterns obtained in the course of heating from -120 to $70^{\circ} \mathrm{C}$ and evolution of the austenitic (200) r reflection $^{2}$ in the course of holding at $-150^{\circ} \mathrm{C}$ (the insert in the upper right corner) (a), corresponding change in tetragonality of martensite $(b)$. 
hypotheses [16] and [17], such frozen Snoek atmospheres should cause additional components in Mössbauer spectrum of the virgin $\mathrm{Fe}-\mathrm{C}$ martensite and their disappearance during heating, which is not observed.

The second possibility is to attribute the partial recovery of tetragonality to some coherent stresses appearing in the course of martensite ageing. These stresses are supposed to be caused by spinodal-like decomposition of the virgin martensite and formation of carbon-rich and carbon-depleted areas.

The analogy to this case can be found in the studies of tetragonality of the carbon-free $\mathrm{Fe}-\mathrm{Ni}$ martensites with the $\mathrm{Ni}$ content in the invar area. The spinodal-like decomposition in instead of I the $\mathrm{Fe}-\mathrm{Ni}$ invar alloys was demonstrated in [65]. The short-range decomposition in the austenitic $\mathrm{Fe}-\mathrm{Ni}$ alloy was also proven by X-ray diffraction and TEM studies, based on the theoretical calculations of $\mathrm{Fe}-\mathrm{Fe}, \mathrm{Fe}-\mathrm{Ni}$ and $\mathrm{Fe}-$ $\mathrm{Ni}$ interatomic bonds and different hydrogen solubility, correspondingly different dilatation in the Fe-rich and Ni-rich areas of the $\mathrm{Fe}-\mathrm{Ni}$ solid solution [66].

A fragment of diffraction pattern of the $\mathrm{Fe}-33.5 \mathrm{Ni}$ alloy after austenitizing at $1150^{\circ} \mathrm{C}$ and cooling down to $10 \mathrm{~K}$ is presented in Fig. 8 (see about detail [67]). The doublet $(112)_{\alpha^{\prime}} /(211)_{\alpha^{\prime}}$ in the as-quenched state, see Fig. 8, $a$, is the evidence of tetragonality in the martensite lattice in absence of carbon. A slight deformation at $40 \mathrm{~K}$ by a screw mounted in the cryostat led to a decrease in the $c / a$ ratio (Fig. 8, $b$ ). After further slight deformation at $110 \mathrm{~K}$, tetragonality disappears (Fig. $8, c)$. It also disappears without any deformation due to increase in mobility of dislocations during heating in the temperature range between $110 \mathrm{~K}$ and $200 \mathrm{~K}$.

This experiment clearly indicates to coherent stresses as a source for tetragonality of the virgin martensite. The nature of this coherency can be of two kinds: (i) coherent stresses at the interface between virgin martensite and retained austenite, as proposed in [67] and (ii) stresses caused by different dilatation in the Fe-rich and Ni-rich areas because of the short-range decomposition. The Ni-rich areas in the austenitic invar alloy are characterized by Langevin superparamagnetism and, correspondingly, a large volume magnetostriction in superparamagnetic clusters, which is inherited by the virgin martensite formed due to quenching at low temperatures.

Similar way, the increase in the $c / a$ ratio during heating of the isothermal martensite from $-50^{\circ} \mathrm{C}$ to RT (see Fig. $7, b$ ) can be related to stresses caused in the aged martensite by its spinodal decomposition.

\section{CONCLUSIONS}

1. Mössbauer studies of the as-quenched binary $\mathrm{Fe}-\mathrm{C}$ martensite formed at temperatures below $\mathrm{RT}$ revealed the distribution of carbon 


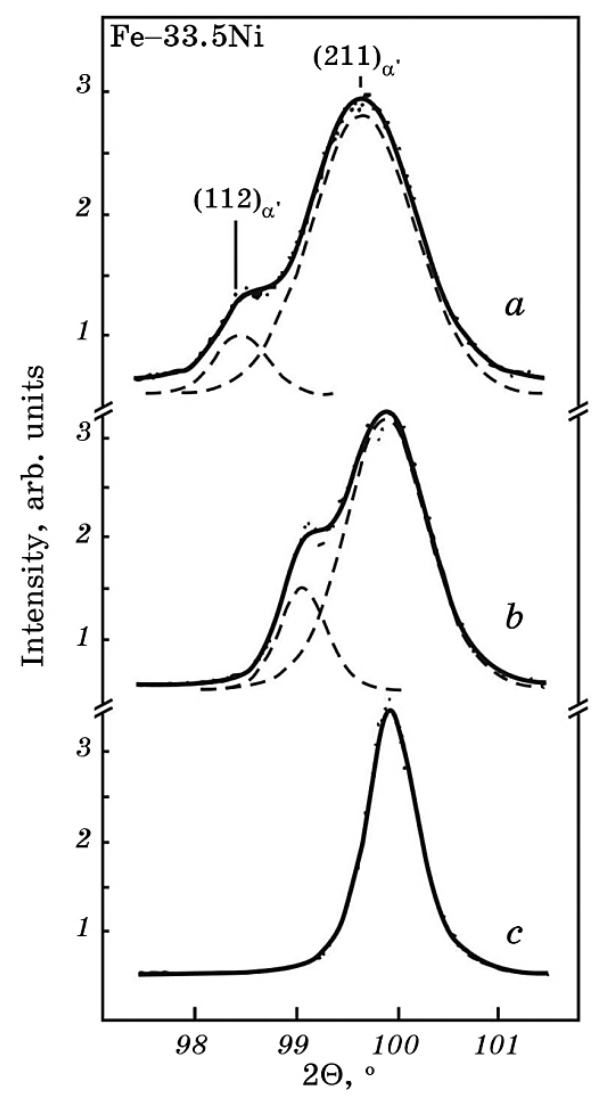

Fig. 8. The effect of in situ deformation on the diffraction peaks (112) $\alpha_{\alpha^{\prime}}$ and (211) ${ }_{\alpha^{\prime}}$ of the virgin $\mathrm{Fe}-33.5 \%$ mass $\mathrm{Ni}$ martensite with $M_{\mathrm{s}}=125 \mathrm{~K}$ after austenitizing at $1150^{\circ} \mathrm{C}$ and cooling down to $4 \mathrm{~K}$ : undeformed $(a)$; deformed at $40 \mathrm{~K}(b)$; further deformed at $110 \mathrm{~K}(c)$. Measurements are carried out at $40 \mathrm{~K}$.

atoms solely in one of three sublattices of the octahedral interstitial sites in the b.c.c. iron lattice, and no sign of carbon localization in other sublattices or in the tetrahedral sites was detected.

2 . The low-temperature isothermal martensitic transformation in carbon steels is accompanied by plastic deformation, which can be explained by the softness of the transformed virgin martensite.

3 . The abnormally low tetragonality of the virgin isothermal martensite is attributed to the capture and transport of immobile carbon atoms by gliding dislocations removing a part of carbon atoms from the $\alpha$ solid solution and resulting in formation of carbon atmospheres around the dislocations.

4. Two possible reasons for partial recovery of tetragonality during the 
heating of virgin isothermal martensite above $-50^{\circ} \mathrm{C}$ are discussed in terms of the unfreezing of Snoek carbon atmospheres created by gliding dislocations at low temperatures or coherent stresses arising from the decomposition of the aged martensite into the carbon-rich and carbon-depleted domains with formation of the modulated structure.

\section{REFERENCES}

1. G. V. Kurdyumov and O. P. Maximova, Reports of AS USSR, 61: 83 (1948).

2. C. Benedics, J. Iron Steel Inst., 77: 233 (1908).

3. $\quad$ E. C. Bain, Chem. Met. Eng., 26: 543 (1922).

4. S. S. Steinberg, Metallurg., 4: 68 (1930) (in Russian).

5. V. D. Sadovsky and I. V. Shtishevskaya, Proc. UFAS USSR, 9: 45 (1937) (in Russian).

6. V. A. Lobodyuk and E. I. Estrin, Uspekhi Fizicheskikh Nauk, 175, No. 7: 745 (2005) (in Russian).

7. V. A. Lobodyuk and E. I. Estrin, Martensitic Transformations (Cambridge: Cambridge International Science Publishing: 2015).

8. J. Pietikainen, J. Iron Steel Inst., 206: 74 (1968).

9. J. Pietikainen, Trans. Iron and Steel Inst. of Japan, 25, No. 4: 340 (1985).

10. G. T. Eldis and M. Cohen, Metall. Trans. A, 14, Iss. 6: 1007 (1983).

11. V. N. Gridnev, V. G. Gavriljuk, V. V. Nemoshkalenko, Yu. A. Polushkin, and O. N. Razumov, Fiz. Met. Metalloved., 43, No. 3: 582 (1977) (in Russian).

12. L. I. Lysak and Ya. N. Vovk, Fiz. Met. Metalloved., 20, No. 4: 540 (1965) (in Russian).

13. L. I. Lysak and V. Ye. Danilchenko, Fiz. Met. Metalloved., 32, No. 3: 639 (1971) (in Russian).

14. L. I. Lysak and L. O. Andrushchik, Fiz. Met. Metalloved., 26, No. 2: 380 (1968) (in Russian).

15. L. I. Lysak and S. P. Kondratiev, Fiz. Met. Metalloved., 30, No. 5: 973 (1970) (in Russian).

16. L. I. Lysak and B. I. Nikolin, Fiz. Met. Metalloved., 22, No. 5: 730 (1966) (in Russian).

17. A. L. Roytburd and A. G. Khachaturyan, Fiz. Met. Metalloved., 30, No. 6: 1189 (1970) (in Russian).

18. D. A. Mirzayev, S. V. Rushits, A. I. Ustinov, and Yu. H. Goykhenberg, Metallofizika, 4, No. 4: 43 (1982) (in Russian).

19. M. Watanabe and C. M. Wayman, Scr. Metall., 5, Iss. 2: 109 (1971).

20. L. I. Lysak, A. G. Drachinskaya, and N. A. Storchak, Fiz. Met. Metalloved., 34, No. 1: 84 (1972) (in Russian).

21. L. I. Lysak, S. A. Artemyuk, and Yu. M. Polyshchuk, Fiz. Met. Metalloved., 35, No. 5: 1098 (1973) (in Russian).

22. L. K. Mykhaylova, Reports of AS USSR, 216, No. 4: 778 (1974).

23. G. V. Kurdyumov and A. G. Khachaturyan, Acta Metall., 23, Iss. 9: 1077 (1975).

24. J. R. Entin, V. A. Somenkov, and S. Sh. Shylstein, Dokl.Akad. Nauk USSR, 206: 1096 (1972) (in Russian).

25. V. G. Gavriljuk, V. N. Gridnev, V. V. Nemoshkalenko, O. N. Razumov, and 
Yu. A. Polushkin, Fiz. Met. Metalloved., 43, No. 3: 582 (1977) (in Russian).

26. H. Ino, T. Ito, S. Nasu, and U. A. Gonser, Acta Metall., 30: 9 (1982).

27. J.-M. Genin, Metall. Trans. A, 18: 1371 (1987).

28. V. G. Gavriljuk, W. Theisen, V. V. Sirosh, E. V. Polshin, A. Kortmann, G. S. Mogilny, Yu. N. Petrov, and Ye. V. Tarusin, Acta Mater., 61: 1705 (2013).

29. D. E. Kaputkin, Mat.Sci.Eng.A, 438-440: 207 (2006).

30. P. M. Gielen and R. Kaplow, Acta Metall., 15: 49 (1967).

31. T. Moriya, H. Ino, and F. E. Fujita, J. Phys. Soc. Japan, 24: 60 (1968).

32. M. Lesoille and P. M. Gielen, Metall. Trans., 3: 2681 (1972).

33. R. I. Entin, V. A. Somenkov, and S. S. Shilstein, Reports of AS USSR, 5: 1096 (1972) (in Russian).

34. W. K. Choo and R. W. Kaplow, Acta Metall., 21: 725 (1973).

35. N. de Cristopharo and R. Kaplow, Metall. Trans. A, 8: 35 (1977).

36. A. L. Sozinov, A. G. Balanyuk, and V. G. Gavriljuk, Acta Mater., 45: 225 (1997).

37. O. N. C. Uwakweh, J. Ph. Bauer, and J.-M. R. Genin, Metall. Trans. A, 21: 589 (1990).

38. J. Foct, J. P. Senateur, J. M. Dubois, and G. le Caer, J. Phys. Colloques, 40: C2-647 (1979).

39. J. Foct, G. Le Caer. J. M. Dubois, and R. Faivri, Veglici, Borki, Azotki w Stalakh (Poznan: Politecn. Poznan: 1978), p. 225.

40. R. Ingalls, Phys. Rev., 133, Iss. 3A: 787 (1964).

41. R. E. Watson, A. C. Gossard, and J. Jafet, Phys. Rev., 140, Iss. 1A: 375 (1965).

42. M. H. Cohen and F. Reif, Solid. Phys., 5: 321 (1957).

43. R. A. Taylor, L. Chang, G. B. Olson, G. D. W. Smith, M. Cohen, and J. B. Wander Sande, Metall. Trans. A, 20: 2717 (1989).

44. O. N. C. Uwakweh, J.-M. R. Genin, and J.-F. Silvain, Metall. Trans. A, 22, Iss. 4: 797 (1991).

45. V. O. Sirosh, A. I. Tyshchenko, G. S. Mogilnyi, Yu. M. Petrov, E. V. Polshin, and V. G. Gavriljuk, Metallofiz. Noveishie Tekhnol., 36, No. 7: 871 (2014) (in Russian).

46. D. V. Wilson, Acta Metall., 5: 293 (1957).

47. J. K. Tien, A. W. Thompson, I. M. Bernstein, and R. J. Richards, Metall. Trans. A, 7, Iss. 6: 821 (1976).

48. A. J. West and M. R. Louthan, Metall. Trans. A, 10, Iss. 11: 1675 (1979).

49. G. S. Frankel and R. M. Lataqnision, Metall. Trans. A, 17, Iss. 5: 861 (1986).

50. M. A. Matosyan and V. M. Golikov, Protective Coatings on Metals (Kiev: Naukova Dumka: 1970), vol. 3, p. 57 (in Russian).

51. T. N. Lipchin, L. G. Chernuka, A. U. Pavlova, and V. I. Suntsev, Metal Science and Heat Treatment of Metals, Iss. 2: 66 (1973) (in Russian).

52. L. N. Larikov, V. F. Mazanko, V. M. Falchenko et al., Reports of Academy of Sciences of Ukrainian SSR, Iss. 7: 636 (1975) (in Russian).

53. I. M. Karnaukhov, O. Ye. Pogorelov, and M. S. Chernolevs'ky, Metallofiz. Noveishie Tekhnol., 28, No. 6: 827 (2006) (in Russian).

54. M. V. Belous and V. T. Cherepin, Fiz. Met. Metalloved., 12, No. 5: 685 (1961) (in Russian).

55. V. N. Gridnev, V. G. Gavriljuk, I. Ya. Dekhtyar, Yu. Ya. Meshkov, V. G. Prokopenko, and P. S. Nizin, phys. status solidi (a), 14, Iss. 2: 689 
(1972).

56. V. G. Gavriljuk, Fiz. Met. Metalloved., 45, No. 5: 969 (1978) (in Russian).

57. V. N. Gridnev and V. G. Gavriljuk, Physics of Metals (USSR), 4, No. 3: 531 (1982).

58. V. G. Gavriljuk, Mat. Sci. Eng. A, 345: 81 (2003).

59. Yu. Ivanisenko, W. Lojkowski, R. Z. Valiev, and H.-J. Fecht, Acta Mater., 51: 5555 (2003).

60. Y. J. Li, P. Choi, C. Borchers, S. Westerkamp, S. Goto, D. Raabe, and R. Kirchheim, Acta Mater., 59: 3965 (2011).

61. A. H. Cottrell and B. A. Bilby, Proc. Phys. Soc. A, 62: 49 (1949).

62. M. A. Shtremel, B. Winderlich, and F. F. Sagdarova, Fiz. Met. Metalloved., 47, No. 4: 754 (1979) (in Russian).

63. A. Inoue, T. Ogura, and T. Masumoto, J. Jap. Inst. Metals, 37, No. 8: 875 (1973).

64. A. Inoue, T. Ogura, and T. Masumoto, Metall. Trans. A, 8, Iss. 11: 1689 (1975).

65. F. A. Garner and J. M. McCarthy, Physical Metallurgy of Controlled Expansion Invar-Type Alloys (Eds. K. C. Russel and D. F. Smith) (Warendale, PA: TMS-AIME: 1990), p. 187.

66. D. N. Movchan, V. N. Shyvanyuk, B. D. Shanina, and V. G. Gavriljuk, phys. status solidi (a), 207, Iss. 8: 1796 (2010).

67. K. Ullakko and V. G. Gavriljuk, Acta Metallurgica et Materialia, 40, Iss. 10: 2471 (1992). 